\title{
Note on style, dates and terminology
}

Spelling and punctuation has been kept as it appears in original documents, except that abbreviations are expanded and $\mathrm{u} / \mathrm{v}, \mathrm{i} / \mathrm{j}$ and vv have been modernised. Short titles of early printed works have been given throughout. Dates are given according to the old-style calendar, but the start of the year is taken as I January, rather than 25 March.

In this study I have attempted, where appropriate and where possible, to use terms that people in the Elizabethan period may have been familiar with. For example, the words 'forward', often used to describe advanced or zealous reforming opinions, and 'froward', meaning refractory, ungovernable or even rebellious, can be found regularly in sixteenth-century texts. In this vein, I have used the term 'forward Protestant', as coined by Blair Worden in The Sound of Virtue, as 'a term contemporaries would have understood' to mean those who were zealous in the quest for further reformation of the church and who 'sought the vigorous advancement of Protestantism at home and abroad'. 'To refer to the sixteenth-century Muscovite state, I have used the words 'Russia' and 'Muscovy' interchangeably, as did the sixteenth-century Englishmen exploring and trading there. I have also regularly used the word 'emperor' to refer to the ruler of Muscovy, or Russia, in imitation of the title attributed to the Russian monarch (tsar) by Englishmen trading and negotiating with Ivan IV and Feodor I. The Muscovy Company accounts and royal correspondence invariably referred to the Russian ruler as 'emperor', as did those who were involved in direct diplomatic audiences with Ivan and Feodor. At times, I have also used the term 'tsar', which is a word more commonly used by scholars of Russian history to describe the rulers of Russia in the sixteenth and seventeenth centuries.

\section{NOTES}

I B. Worden, The Sound of Virtue: Philip Sidney's Arcadia and Elizabethan Politics (New Haven and London: Yale University Press, I996), p. xxii. 
Blank page

Felicity Jane Stout - 9781784996871 Downloaded from manchesterhive.com at 04/26/2023 08:33:10AM via free access 